\title{
KOMUNIKASI DALAM MEMBENTUK IKLIM ORGANISASI DI LINGKUNGAN KAMPUS UNIVERSITAS ISLAM NEGERI (UIN) AR-RANIRY BANDA ACEH
}

\author{
Heri Rahmatsyah Putra \\ STAIN Tengku Dirundeng Meulaboh \\ E-mail: herirahmatsyahputra@staindirundeng.ac.id
}

\begin{abstract}
Abstrak
Penelitian ini bertujuan untuk mengetahui proses komunikasi organisasi antara dosen dan pegawai dalam membentuk iklim organisasi sebagai upaya meningkatkan kepuasan mahasiswa Universitas Islam Negeri Ar-Raniry Banda Aceh. Dalam melakukan penelitian ini, peneliti menggunakan pendekatan kualitatif dengan menggunakan teknik wawancara dengan beberapa anggota organisasi yaitu dosen, pegawai, dan mahasiswa. Peneliti juga melakukan pengamatan langsung di lima fakultas di UIN Ar-Raniry. Dari hasil penelitian yang dilakukan menunjukkan bahwa proses komunikasi organisasi yang selama ini berlangsung antara dosen, pegawai, dan mahasiswa masih belum berjalan secara efektif. Hal ini disebabkan karena adanya miscommunication yang terjadi serta kinerja pelayanan pegawai yang kurang memuaskan. Padatnya jadwal beberapa orang dosen juga menjadi permasalahan dalam meningkatkan kepuasan mahasiswa. Komunikasi organisasi yang terjadi secara linier, top down, bahkan sirkular juga belum terbentuk secara menyeluruh dan efektif. Hal ini yang kemudian membentuk iklim organisasi yang tertutup. Iklim komunikasi organisasi yang tertutup selama ini telah menjadi faktor penghambat komunikasi dosen dan pegawai dalam meningkatkan kepuasan mahasiswa UIN Ar-Raniry.
\end{abstract}

Kata kunci: Komunikasi, Iklim Organisasi

\begin{abstract}
The study aims to determine the organizational communication process between lecturers and staff in shaping the organizational climate as an effort to increase student satisfaction at the Ar-Raniry State Islamic University in Banda Aceh. In conducting this research, researchers used a qualitative approach using interview techniques with several members of the organization namely lecturers, employees, and students. Researchers also made direct observations at five faculties at UIN Ar-Raniry. From the results of the research conducted showed that the organizational communication process that has been going on between lecturers, staff, and students is still not running effectively. This is due to miscommunication that occurs as well as unsatisfactory employee service performance. The tight schedule of several lecturers is also a problem in increasing student satisfaction. Organizational communication that occurs linearly, top down, even circularly has not yet been formed as a whole and effectively. This then forms a closed organizational climate. The closed climate of organizational communication has
\end{abstract}


been a limiting factor for the communication of lecturers and staff in increasing the satisfaction of UIN Ar-Raniry students.

\section{Keywords: Communication, organizational climate}

\section{PENDAHULUAN}

Komunikasi dapat terjadi pada siapa saja, dimana saja, dan kapan saja. Sedari lahir manusia telah melakukan kegiatan berkomunikasi. Hal ini dibuktikan dengan menangisnya setiap bayi yang baru lahir. Menangis ialah satu-satunya cara bayi berkomunikasi dengan orang-orang di sekitarnya. Seiring pertumbuhan manusia, komunikasi akan terus terjadi sampai akhirnya seorang manusia itu meninggal dunia. Sebagai makhluk sosial manusia senantiasa ingin berhubungan dengan manusia satu sama lainnya. Komunikasi merupakan setiap proses pertukaran informasi, gagasan, dan perasaan. Proses ini meliputi informasi yang disampaikan, baik lisan maupun secara tertulis, dengan kata-kata, atau yang disampaikan dengan bahasa tubuh, gaya maupun penampilan diri, menggunakan alat bantu di sekeliling kita sehingga sebuah pesan menjadi lebih kaya. Everet M. Rogers seorang pakar sosiologi pedesaan Amerika yang kemudian lebih banyak memberi perhatian pada studi riset komunikasi khususnya dalam hal penyebaran inovasi membuat definisi komunikasi, komunikasi adalah proses di mana suatu ide dialihkan dari sumber kepada satu penerima atau lebih dengan maksud untuk mengubah tingkah laku mereka. ${ }^{1}$

Berdasarkan ruang lingkupnya, maka komunikasi dapat dibedakan atas beberapa macam, yaitu salah satunya ialah komunikasi organisasi. Ada bermacammacam pendapat mengenai apa yang dimaksud dengan organisasi. Seperti dikutip di dalam buku Komunikasi Organisasi Schein mengatakan bahwa organisasi adalah suatu koordinasi rasional kegiatan sejumlah orang untuk mencapai beberapa tujuan umum melalui pembagian pekerjaan dan fungsi melalui hierarki (pangkat jabatan) otoritas dan tanggung jawab. Schein juga mengatakan bahwa organisasi mempunyai karakteristik tertentu yaitu mempunyai struktur, tujuan, saling berhubungan antara satu bagian dengan bagian yang lain. Sedangkan Kochler

${ }^{1}$ Hafied Cangara, Perencanaan dan Strategi Komunikasi, (Jakarta: PT Raja Grafindo Persada, 2014) h. 35 
mengatakan bahwa organisasi adalah sistem hubungan yang terstruktur yang mengkoordinasi usaha suatu kelompok orang untuk mencapai tujuan tertentu. ${ }^{2} \mathrm{Di}$ dalam kegiatan organisasi, komunikasi tentunya sangat dibutuhkan karena dengan adanya komunikasi maka kegiatan dalam organisasi dapat berjalan sesuai dengan harapan dan tujuan.

Universitas merupakan salah satu organisasi formal yang bergerak dalam bidang pendidikan. Universitas ataupun yang sering kita sebut dengan istilah kampus dapat dikatakan sebagai miniatur negara yang berisi masyarakat kampus, tatanan pemerintahan hingga social society yang memiliki peran yang penting. Kesadaran akan pentingnya komunikasi dalam lingkungan kampus harus diterapkan oleh masyarakat kampus itu sendiri. Pentingnya membangun komunikasi yang baik dan tepat akan membantu terjadinya penyebaran informasi yang efektif. Sehingga tidak akan lagi hadir permasalahan kampus yang terkait dengan komunikasi. Komunikasi berdasarkan ruang lingkupnya terbagi dalam beberapa macam, salah satunya adalah komunikasi organisasi. Komunikasi organisasi sendiri merupakan komunikasi yang terbangun dalam sebuah lembaga yang memainkan peran komunikasi, artinya komunikasi terjadi dari atasan kepada bawahan (vertikal), sesama pegawai (horizontal), dan lain sebagainya. ${ }^{3}$

Berdasarkan pembahasan di atas, jika ditinjau dari segi komunikasi, dosen terkadang termasuk kedalam komunikan dan terkadang juga sebagai komunikator, begitu pula halnya pegawai. Kemudian tinjauan organisasi sebagai proses adalah memperhatikan dan menyoroti interaksi antar orang-orang yang menjadi anggota organisasi itu yang merupakan kelompok orang-orang yang berfikir dan bertindak secara tertentu. Sebagai suatu proses, organisasi jauh lebih dinamis daripada sebagai wadah. ${ }^{4}$ Kesalahpahaman dalam proses komunikasi organisasi antara dosen dan pegawai tentu akan berdampak terhadap kelancaran kegiatan administrasi mahasiswa. Tidak jarang mahasiswa mengalami kendala dalam kelancaran segala aktifitas, baik dalam urusan akademisi maupun dalam proses belajar mengajar. Seperti pada masalah pengumpulan berkas kartu rencana studi (KRS) yang telah

\footnotetext{
${ }^{2}$ Arni Muhammad, Komunikasi Organisasi, Cet. ke II, (Jakarta: Bumi Aksara, 1995) h. 4

${ }^{3}$ Ibid, h. 66.

${ }^{4}$ Onong Ujana Effendy, Dinamika Komunikasi, (Bandung: Remaja Rosda Karya, 1986) h.
} 135. 
ditentukan tempo waktunya. mahasiswa harus segera mengumpulkan KRS agar dapat mengikuti proses perkuliahan. Pada masalah pengisian KRS, mahasiswa terkadang menemukan beberapa kesalahpahaman akibat miscommunication antara dosen dan pegawai. Seperti dalam hal penyetujuan jumlah mata kuliah yang akan disetujui. Ketika mahasiswa berkonsultasi dengan dosen penasehat akademik (PA) untuk mengajukan jumlah SKS yang akan diambil. Tetapi dari pihak pegawai akademik tidak menyetujui keputusan yang telah disetujui oleh dosen PA. Sehingga mahasiswa bersangkutan mengalami kebingungan tentang siapa yang sebenarnya berhak menentukan jumlah SKS yang harus diambil. Untuk mengatasi hal ini tentu saja pihak dosen dan pegawai seharusnya memiliki kesepakatan agar tidak terjadi kendala pada mahasiswa. Dalam permasalahan lain, mahasiswa juga menjadi pihak yang dirugikan dalam urusan akademisi. Misalkan dalam mengajukan permohonan bimbingan skripsi. Dalam beberapa kasus, mahasiswa dibingungkan dengan penunjukan dosen pembimbing skripsi yang terkadang malah tidak bersedia ditunjuk sebagai dosen pembimbing. Kenyataannya surat pengajuan bimbingan tersebut dikeluarkan oleh pihak jurusan. Seharusnya ada koordinasi lebih dulu dari dosen jurusan kepada dosen yang ditunjuk sebagai pembimbing untuk membimbing skripsi mahasiswa. Tentu saja mahasiswa sebagai pihak yang siap menerima keputusan tentang penunjukan dosen pembimbing ini akan mengalami kendala yang akan mempengaruhi keberlangsungan pembuatan skripsinya.

Bahkan tidak sedikit, ternyata beberapa mahasiswa mengetahui adanya beberapa pihak dosen yang memang tengah mengalami hubungan yang buruk antara sesama dosen dan pegawai akademik. Hal ini diakibatkan adanya keadaankeadaan yang mengutamakan ego kekuasaan dan latar belakang pemikiran yang berbeda. Tentu saja mahasiswa sebagai pihak yang tidak berwenang menjadi korban dari dampak hubungan yang buruk tersebut. Seharusnya permasalahanpermasalahan internal yang tidak dapat terelakkan itu tidak berdampak kepada mahasiswa. Karena para dosen dan pegawai mempunyai keharusan untuk mengurusi perihal kegiatan mahasiswa, maka memerlukan suatu proses komunikasi yang baik dan terencana demi tercapainya keberhasilan peningkatan kepuasan pada mahasiswa. Selain masalah-masalah yang disebutkan di atas, masih ada dijumpai masalah lain yang disebabkan oleh kesalahpahaman proses komunikasi organisasi 
antara dosen dan pegawai dalam universitas. Berdasarkan permasalahan yang telah diuraikan di atas, maka penulis ingin mengetahui bagaimana iklim komunikasi organisasi yang terjadi pada kampus UIN Ar-Raniry. Kemudian dalam hal ini penulis menetapkan sebuah judul penelitian yang berjudul "Proses Komunikasi Antara Dosen dengan Pegawai dalam Membentuk Iklim Organisasi di Lingkungan Kampus Universitas Islam Negeri (UIN) Ar-Raniry Banda Aceh". Adapun yang menjadi rumusan masalah dalam penelitian ini ialah bagaimana proses komunikasi antara dosen dengan pegawai di kampus UIN Ar-Raniry dalam membentuk iklim organisasi. Penelitian ini bertujuan untuk mengetahui proses komunikasi antara dosen dengan pegawai dalam membentuk iklim organisasi di lingkungan kampus UIN Ar-Raniry Banda Aceh. Penelitian ini diharapkan dapat bermanfaat untuk menambah pengetahuan dalam ilmu komunikasi khususnya bidang komunikasi organisasi serta dapat menjadi bahan referensi bagi dosen dan pegawai untuk menciptakan komunikasi yang baik dan efektif agar terciptanya iklim organisasi yang sehat untuk mencapai tujuan organisasi.

\section{KONSEP TEORI}

\section{Komunikasi Organisasi}

Organisasi adalah perkumpulan, kelompok kerjasama antara orang-orang yang diadakan untuk mencapai tujuan bersama, susunan dan aturan dari berbagai organ dan sebagainya sehingga merupakan kesatuan yang teratur. ${ }^{5}$ Organisasi juga merupakan tempat dimana kegiatan manajemen dijalankan.Sebagai wadah suatu pola dasar struktur organisasi relatif permanen sifatnya, artinya susunan organisasi tidak sebentar-sebentar dirubah. ${ }^{6}$ Interaksi manusia dalam sebuah organisasi merupakan sebuah keharusan.Tidak mungkin sebuah organisasi berjalan dengan baik, apabila tidak ada interaksi dari anggotanya.Interaksi anggota organisasi hanya dapat terlaksana dengan adanya komunikasi yang dilakukan.Komunikasi merupakan aspek yang sangat penting dalam sebuah organisasi. Komunikasi dalam organisasi ialah suatu proses penyampaian informasi, ide-ide antara para anggota organisasi secara timbal balik dalam rangka mencapai tujuan yang telah ditetapkan.

\footnotetext{
${ }^{5}$ Windy Novia, Kamus Lengkap Bahasa Indonesia, (Surabaya: Kashiko Press) h. 320

${ }^{6}$ Arni Muhammad, Dasar-dasar Organisasi, (UUI Press Jogjakarta: Jogjakarta), h.1
} 
Komunikasi organisasi pada dasarnya merupakan suatu kegiatan intern dalam organisasi. $^{7}$

Dalam buku Sosiologi Komunikasi didefinisikan bahwa komunikasi organisasi adalah komunikasi antar manusia (human communication) yang terjadi dalam konteks organisasi di mana terjadi jaringan-jaringan pesan satu sama lain yang saling bergantungan satu sama lain. ${ }^{8}$ Menurut Kart dan Kahn, mengatakan bahwa komunikasi organisasi adalah arus informasi, pertukaran informasi dan pemindahan arti dari suatu organisasi. Sementara itu, Burhan Bungin dalam bukunya Sosiologi Komunikasi mengatakan bahwa komunikasi organisasi adalah komunikasi antar manusia (human communication) yang terjadi dalam konteks organisasi dimana terjadi jaringan-jaringan pesan yang saling bergantung satu sama lain. ${ }^{9}$ Komunikasi organisasi menurut Goldhaber didefinisikan sebagai proses menciptakan dan saling menukar pesan dalam suatu jaringan hubungan yang saling tergantung satu sama lain untuk mengatasi lingkungan yang tidak pasti atau yang saling berubah-ubah. Komunikasi organisasi adalah proses penciptaan makna atas interaksi yang menciptakan, memelihara, dan mengubah organisasi. ${ }^{10}$

Komunikasi dalam organisasi dapat menentukan jalannya proses suatu organisasi dalam mencapai tujuannya. Komunikasi akan selalu terjadi dalam setiap kegiatan organisasi dengan tujuan untuk mencapai tujuan organisasi. Kesuksesan organisasi sangat dipengaruhi oleh kapasitas dan kompetensi masing-masing individual dan kerjasama antar anggota tim dalam organisasi. Dalam menjalin kerjasama untuk mencapai tujuan tersebut diperlukan adanya komunikasi. Ditinjau berdasarkan teknis pelaksanaannya, komunikasi dapat dirumuskan sebagai kegiatan dimana seseorang menyampaikan pesan melalui media tertentu kepada orang lain dan sesudah menerima pesan serta memahami sejauh mana kemampuannya, penerima pesan menyampaikan tanggapan melalui media tertentu kepada orang yang menyampaikan pesan tersebut kepadanya.

\footnotetext{
${ }^{7}$ Wursanto, Dasar-Dasar Ilmu Organisasi, (Yogyakarta: Andi, 2003) h. 157

${ }^{8}$ Bungin, Sosiologi, h. 278.

${ }^{9}$ Ibid, h. 273.

${ }^{10}$ Gerald M. Goldhaber, Organizational Communication, (USA: Brown Publisher, 1990)
} h. 47 . 


\section{Iklim Komunikasi Organisasi}

Iklim komunikasi terdiri dari dua kata yaitu 'iklim' dan 'komunikasi'. Secara etimologi kata iklim berarti suasana seseorang kepada orang lain. ${ }^{11}$ Sementara komunikasi adalah proses penyampaian suatu pesan oleh seseorang kepada orang lain untuk memberi tahu atau merubah sikap, pendapat atau perilaku.

Baik langsung secara lisan, maupun tidak langsung melalui pendapat. ${ }^{12}$ Istilah 'Iklim' merupakan kiasan (metafora). Frase 'iklim komunikasi organisasi' menggambarkan suatu kiasan bagi iklim fisik. Cara orang bereaksi terhadap aspek organisasi menciptakan suatu iklim komunikasi. Dalam ilmu komunikasi, iklim komunikasi adalah lingkungan atau situasi yang menjadi faktor penentu berlangsungnya komunikasi. Ada empat penentu terjadinya komunikasi, yaitu; lingkungan fisik, lingkungan sosial budaya, dimensi psikologi, dan dimensi waktu. $^{13}$

Kurt Lewin seorang psikolog-sosial, pada tahun 1940 sampai 1950-an meneliti sejauh mana pengaruh situasi dan kondisi sosial mempengaruhi kehidupan, aktivitas individual, maupun kelompok. Lewin menyebutkan eksperimen ini sebagai penelitian tentang 'iklim sosial' (social climate). Konsep Lewin ini kemudian diintroduksi ke dalam studi organisasi maupun manajemen sehingga sekitar tahun 1960-an banyak psikolog, sosiolog, maupun antropolog meneliti iklim (sosial) dalam organisasi. ${ }^{14}$ Iklim komunikasi di pihak lain merupakan gabungan dari persepsi-persepsi suatu evaluasi makro mengenai peristiwa komunikasi, perilakumanusia, respons pegawai terhadap pegawai lainnya, harapan-harapan, konflik-konflik antarpersona, dan kesempatan bagi pertumbuhan dalam organisasi tersebut. Iklim komunikasi berbeda dengan iklim organisasi dalam artian iklim komunikasi meliputi persepsi-persepsi mengenai pesan dan peristiwa yang berhubungan dengan pesan yang terjadi dalam organisasi. ${ }^{15}$

Iklim organisasi adalah 'iklim psikologis' yang dapat diukur melalui persepsi individu atau persepsi kelompok terhadap apa yang dikerjakan, persepsi

\footnotetext{
${ }^{11}$ Kamus, h. 185

${ }^{12}$ Effendy, Dinamika, h. 5

${ }^{13}$ Cangara, Pengantar, h. 26

${ }^{14}$ Pace, Komunikasi, h. 146

${ }^{15}$ Ibid, h. 146
} 
terhadap relasi antara pekerja, antara pekerja dengan manajer, antara para manajer, dan persepsi terhadap relasi antara pekerja/manajer/organisasi dengan berbagai pihak di luar lingkungan organisasi (external organization). Iklim organisasi diartikan sebagai pola-pola perilaku, sikap, dan perasaan yang ditampilkan berulang-ulang yang dijadikan sebagai karakteristik kehidupan organisasi. ${ }^{16}$ Dikutip dalam buku Sosiologi dan Komunikasi Organisasi, studi yang pernah dilakukan oleh J.R. Gibb (1979) tentang iklim organisasi menunjukkan, iklim organisasi ternyata sangat ditentukan oleh iklim komunikasi, khususnya yang berkaitan dengan daya guna yang relevan atas private language of an organization (bahasa organisasi) yang menciptakan relasi antarmanusia yang beragam dalam organisasi. Gibb menemukan bahwa kelompok-kelompok kecil dalam organisasi bertahan karena mereka mempunyai pola-pola komunikasi tersendiri yang membuat mereka bisa bersikap defensive atau supportive.

Berbagai penelitian mencatat ada lima variable yang diduga mempengaruhi iklim organisasi, yaitu komunikasi, pengambilan keputusan, motivasi pimpinan, perumus tujuan, dan komitmen terhadap organisasi. Jadi, ada hubungan yang erat antara variabel iklim komunikasi dengan iklim organisasi. Oleh karena itu, untuk menciptakan iklim organisasi yang positif maka diciptakan terlebih dahulu iklim komunikasi dan organisasi yang positif. ${ }^{17}$ Iklim komunikasi penting karena mengaitkan konteks organisasi dengan konsep-konsep, perasaan-perasaan, dan harapan-harapan anggota organisasi dan membantu menjelaskan perilaku anggota organisasi (Poole, 1985). Dengan mengetahui sesuatu tentang iklim suatu organisasi, dapat memahami lebih baik apa yang mendorong anggota organisasi untuk bersikap dengan cara-cara tertentu. Beberapa ahli dalam komunikasi organisasi juga berpendapat bahwa konsep iklim merupakan salah satu gagasan paling kaya dalam teori organisasi, secara umum, dan dalam komunikasi organisasi secara khusus. Disebut 'kaya' karena iklim telah mendapat perhatian besar dalam literature teoritis dan empiris. Iklim juga seakan-akan sederhana dan rumit pada saat yang sama, dan memiliki daya penjelas yang cakupannya luas. ${ }^{18}$ Suatu iklim komunikasi berkembang dalam konteks organisasi. Unsur-unsur dasar yang

\footnotetext{
${ }^{16}$ Liliweri, Sosiologi, h. 305

${ }^{17} \mathrm{Ibid}$, h. 323

${ }^{18}$ Pace, Komunikasi, h. 148
} 
membentuk suatu organisasi dapat diringkaskan menjadi lima kategori besar, yaitu: ${ }^{19}$

a. Anggota organisasi

Di pusat organisasi terdapat orang-orang yang melaksanakan pekerjaan organisasi. Orang-orang yang membentuk organisasi terlibat dalam beberapa kegiatan primer. Mereka terlibat dalam kegiatan-kegiatan pemikiran yang meliputi konsep-konsep, penggunaan bahasa, pemecahan masalah, dan pembentukan gagasan.

b. Pekerjaan dalam organisasi

Pekerjaan yang dilakukan anggota organisasi terdiri dari tugas-tugas formal dan informal. Tugas-tugas ini menghasilkan produk dan memberikan pelayanan organisasi. Pekerjaan ini ditandai oleh tiga dimensi universal: isi pesan, keperluan, dan konteks.

c. Praktik-praktik pengelolaan.

Tujuan primer pegawai manajerial adalah menyelesaikan pekerjaan melalui usaha orang lainnya. Manajer membuat keputusan mengenai bagaimana orang-orang lainnya, biasanya bawahan mereka, menggunakan sumber daya yang diperlakukan untuk melaksanakan tugas mereka.

d. Struktur Organisasi.

Merujuk kepada hubungan-hubungan antara "tugas-tugas yang dilaksanakan oleh anggota-anggota organisasi”. Struktur organisasi ditentukan oleh tiga variable kunci: kompleksitas, formalisasi, dan sentralisasi (Robbins, 1989). ${ }^{20}$

e. Pedoman organisasi.

Pedoman organisasi Adalah serangkaian pernyataan yang mempengaruhi, mengendalikan, dan memberi arahan bagi anggota organisasi dalam mengambil keputusan dan tindakan.

${ }^{19}$ Pace, Komunikasi, h. 151

${ }^{20}$ Ibid, h. 151 


\section{Komunikasi Organisasi Dalam Konteks Perguruan Tinggi}

Universitas dan sekolah adalah lembaga yang bersifat komplek dan unik. Bersifat komplek karena universitas sebagai organisasi didalamnya terdapat berbagai demensi yang satu sama lain saling berkaitan dan saling menentukan. Sedang sifat unik, menunjukkan bahwa universitas sebagai organisasi memiliki ciri-ciri tertentu yang tidak dimiliki oleh organisasi-organisasi lain. Ciri-ciri yang menempatkan universitas memiliki karakter sendiri, dimana terjadi proses belajar mengajar, tempat terselenggaranya pembelajaran kehidupan umat manusia. Karena sifatnya yang komplek dan unik tersebutlah, universitas sebagai organisasi memerlukan tingkat koordinasi yang tinggi. ${ }^{21}$

Dosen adalah pendidik profesional dan ilmuwan dengan tugas utama mentransformasikan, mengembangkan, dan menyebarluaskan ilmu pengetahuan, teknologi, dan seni melalui pendidikan, penelitian, dan pengabdian kepada masyarakat. $^{22}$ Dosen juga dapat diartikan sebagai seorang yang berdasarkan pendidikan dan keahliannya diangkat oleh pengajar perguruan tinggi dengan tugas utama mengajar pada perguruan tinggi (PP. No.60/1999) merupakan instrument yang sangat menentukan keberhasilan proses pendidikan, karena dosenlah perpindahan ilmu yang dilakukan kepada mahasiswa.

Dosen dan pegawai merupakan unsur-unsur penggerak dalam sebuah manajemen pendidikan. Sebuah perguruan tinggi tentunya takkan dapat berjalan tanpa adanya kedua unsur tersebut. Pegawai (akademik) sendiri memiliki definisi yaitu orang yang bekerja pada suatu lembaga (kantor, perusahaan, organisasi, dan sebagainya) dengan mendapat gaji. ${ }^{23}$ Sebuah kantor tanpa adanya pegawai ibarat manusia tanpa darah. hal itu menggambarkan betapa pentingnya pegawai dalam sebuah perkantoran atau perusahaan, walaupun banyak pemilik perusahaan yang tidak menyadari tentang hal itu. Tanpa adanya proses komunikasi yang baiik antara atasan dan bawahan, secara disadari atau tidak secara langsung atau tidak langsung, hal-hal tersebut akan sangat berpengaruh terhadap kualitas kerja serta loyalitas pegawai terhadap kinerjanya.

\footnotetext{
${ }^{21}$ Wahjosumidjo.Kepemimpinan Kepala Sekolah, (Jakarta: PT Raja Grafindo, 2005) h. 81 ${ }^{22}$ Undang-undang Republik Indonesia Nomor 14 Tahun 2005 tentang Guru dan Dosen.

${ }^{23}$ Kamus, h. 98
} 
Komunikasi yang dibangun organisasi amat penting perannya, karena ketidaklancaran komunikasi akan sangat tidak menguntungkan efisiensi kinerja organisasi. Akibat tidak efektifnya komunikasi, akan banyak waktu yang tersita siasia, pemborosan kertas, perbaikan yang tak perlu karena informasi yang salah, kekeliruan bawahan dalam melaksanakan perintah, atau kurangnya pengertian anggota organisasi terhadap instruksi yang diberikan seorang pemimpin, berbagai keluhan dari kalangan mahasiswa dan orang tua, serta opini yang tidak menyenangkan dari luar universitas dalam hal ini masyarakat. Oleh sebab itu, pimpinan harus mempelajari, memperhatikan, mancari cara, atau membangun sistem agar komunikasi dapat berjalan dengan cara yang efektif.

Komunikasi yang tidak efektif dalam suatu organisasi sering berpengaruh buruk terhadap produktivitas organisasi. Perlu juga diperhatikan bagi seorang pemimpin, bahwa komunikasinya dengan anggota oragnisasi merupakan pendorong bagi mereka dalam menjalankan tugas sehari-hari. Akibat lain dari komunikasi tidak efektif, adalah turunya minat anggota organisasi terhadap pekerjaan, rendahnya moral kerja, rendahnya tingkat produktivitas, berkurangnya pengawasan terhadap mutu, dan berbagai dampak negatif lain terhadap kinerja organisasi. $^{24}$

\section{METODOLOGI PENELITIAN}

Dalam penelitian ini peneliti menggunakan metode kualitatif yang menghasilkan data yang bersifat deskriptif berupa kata tertulis atau lisan dari orangorang yang diwawancarai. Adapun untuk memperoleh data yang dibutuhkan lebih akurat maka penulis juga mengarahkan pada teknik pengumpulan data dengan cara observasi atau pengamatan langsung ke lapangan. Setelah memperoleh data mentah, peneliti kemudian menganalisis data secara sistematis sehingga dapat disajikan secara deskriptif.

${ }^{24}$ Syahrizal Abbas, Manajemen Perguruan Tinggi: Beberapa Catatan, (Jakarta: Kencana, 


\section{HASIL PENELITIAN}

Proses komunikasi organisasi yang terjadi dalam lingkungan kampus UIN Ar-Raniry ternyata tidak selamanya berjalan dengan efektif. Adanya miscommunication antara dosen dan pegawai telah banyak berpengaruh terhadap mahasiswa. Dalam hal kegiatan perkuliahan (belajar-mengajar), fungsi dosen Penasehat Akademik (PA), dan proses bimbingan skripsi. Proses komunikasi pegawai dalam hal kinerja pelayanan terhadap mahasiswa. Bentuk-bentuk komunikasi organisasi yang terjadi antara pegawai dan dosen di fakultas-fakultas dalam lingkungan UIN Ar-Raniry dominan berlangsung secara secara linier (lurus), top down, bahkan sirkular (adanya feedback) sesuai dengan keadaan yang sedang berlangsung. Semua dosen bisa menjadi komunikator dan komunikan ketika berkomunikasi dengan pegawai. Bentuk komunikasi organisasi yang terjadi tidak jarang juga dapat menjadi komunikasi yang dialogis dalam artian antara pegawai, dosen, dan mahasiswa sama-sama dapat menjadi komunikator yang menyampaikan pesan-pesan yang terkait dengan kemajuan fakultas.

Iklim Komunikasi Organisasi merupakan satu hal yang memegang peranan penting dalam kehidupan suatu organisasi. Kepuasan komunikasi organisasi juga merupakan salah satu hal yang harus menjadi perhatian utama pihak organisasi, karena kepuasan komunikasi organisasi mempengaruhi perilaku orang-orang yang berada di dalam organisasi tersebut. sehingga nantinya organisasi dapat mengambil tindakan yang paling tepat untuk mengembangkan organisasi. Hubungan antara dosen dan pegawai dalam fakultas akan sangat mempengaruhi iklim komunikasi organisasi yang tercipta.

Iklim komunikasi organisasi dapat terwujud dengan adanya proses komunikasi yang baik dan efektif antar anggota organisasi. Pada umumnya komunikasi yang disampaikan oleh komunikator memiliki pengaruh besar terhadap komunikannya. Baik pengaruh yang positif, maupun pengaruh negatif, tergantung respon dari komunikan tersebut. Suatu lembaga pada umumnya juga menginginkan pengaruh positif terhadap komunikasi yang mereka jalankan. Seperti yang diungkapkan oleh Kasubbag akademik kemahasiswaan dan alumni Fakultas Dakwah dan Komunikasi, sebagai pengelola fakultas ia mengaku telah mencoba membangun komunikasi yang baik juga memberi pelayanan yang baik terhadap 
mahasiswa dan dosen. ${ }^{25}$ Kemudian informan lain juga menambahkan bahwa selama ini ia telah meminimalisir kinerja dosen yang kurang baik, seperti menegur dosendosen yang melalaikan mata kuliahnya juga dosen yang memperlambat proses bimbingannya kepada mahasiswa. ${ }^{26}$

Akan tetapi hal tersebut tidak dirasakan oleh salah seorang dosen, ia merasa ada hambatan dalam proses komunikasi dengan pihak pegawai. Proses komunikasi tidak berlangsung seperti seharusnya, ada hal-hal yang seharusnya dikomunikasikan dengan semua dosen, tetapi tidak dilakukan oleh pegawai. Pernyataan yang sama juga disampaikan oleh informan lainnya. Mereka menyayangkan, jika hal seperti ini terus berkelanjutan akan menciptakan iklim komunikasi organisasi yang buruk dalam sebuah organisasi (fakultas) serta berakibat buruk terhadap kelangsungan masa depan fakultas. Seperti yang disampaikan oleh seorang informan, adanya misscomunication antara pegawai dengan dosen seperti dalam hal pembagian tugas, misalnya membuat silabus, idealnya memanggil orang-orang yang berkompenten yang mengerti seluk beluk ilmu tersebut, dan melibatkan mereka tetapi menurut beberapa dosen hal ini tidak dilakukan oleh pihak fakultas.

Sebenarnya dosen mempunyai peran yang signifikan di dalam sebuah perguruan tinggi apalagi fakultas, mereka adalah unit-unit kerja terakhir. Keahlian itu, ada pada setiap dosen, untuk mengupayakan pencapaian tujuan di fakultas, seharusnya dosen-dosen turut dilibatkan. ${ }^{27}$ Selain itu keinginan dosen untuk diadakannya waktu bertemu dosen dan pegawai untuk melakukan pembicaraan, minimal sebulan sekali. Supaya dapat dievaluasi progress kinerja dosen, melihat apa saja kendala-kendala mahasiswa, dosen, fasilitas mengajar dosen misalnya buku teks, bahan-bahan kuliah telah memenuhi standar atau tidak, serta kehadiran dosen. ${ }^{28}$

25 Hasil wawancara penulis dengan Dra. Maqfirah, M. Pd (Kasubbag akademik kemahasiswaan dan alumni Fakultas Dakwah dan Komunikasi) Banda Aceh 8 April 2015

${ }^{26}$ Hasil wawancara penulis dengan Taufiq, SE, Ak, M. Ed (Dosen tetap serta sekretaris Prodi KPI Fakultas Dakwah dan Komunikasi) Banda Aceh 8 April 2015

${ }^{27}$ Hasil wawancara penulis dengan salah seorang dosen Jurusan Manajemen Dakwah, 17 Juni 2014

${ }^{28}$ Hasil wawancara penulis dengan Drs. Bachtiar Ismail, MA (Dosen tetap Fakultas Tarbiyah dan Keguruan) Banda Aceh 7 April 2015 
Melihat dari berbagai pendapat informan di atas, hal tersebut akan sangat mempengaruhi pada proses perkuliahan mahasiswa. Mahasiswa juga merupakan unsur dari sebuah organisasi (fakultas) merupakan tingkatan terbawah yang sangat jarang mendapatkan peluang untuk melakukan komunikasi yang dialogis. Segala dampak komunikasi yang buruk akan mempengaruhi kepada kepuasan mahasiswa. Seperti yang diungkapkan oleh seorang informan, situasi antara dosen dan pegawai di kampus terkadang membuat mengecewakan."Saya pernah mendapatkan nilai E pada mata kuliah yang selalu saya ikuti. Mulai dari ujian midtest sampai final bahkan. Kemudian saya mempertanyakan hal ini kepada dosen yang bersangkutan. Ternyata nilai ujian final belum diserahkan kepada pegawai bidang akademik. Jadi mereka dengan mudah memberikan nilai C pada KHS. Walaupun pada akhirnya nilai itu diperbaiki kembali, sudah pasti melewati proses yang bertele-tele, sangat mengherankan."29

Adanya miscommunication seperti hasil penelitian di atas menunjukkan adanya hubungan yang kurang baik antara dosen dan pegawai akademik kemahasiswaan. Karena dalam hal pemberian nilai sudah seharusnya menjadi wewenang dosen yang mengasuh mata kuliah, kemudian menyerahkan kepada bagian akademik untuk dicantumkan dalam KHS mahasiswa. Akan tetapi ternyata sebagian pegawai tidak melakukan komunikasi terlebih dahulu kepada dosen terkait perihal nilai yang belum masuk kepada mereka. Sehingga mereka langsung mengambil kebijakan bahwa mahasiswa tersebut tidak mengikuti perkuliahan dengan dosen yang bersangkutan.

Seharusnya dosen dan pegawai memiliki komunikasi yang terbuka dan intens terkait dengan urusan kemahasiswaan. Seperti yang diungkapkan oleh salah seorang mahasiswa lain yang menginginkan adanya komunikasi yang terbuka antara dosen dengan pegawai. Ia menilai selama ini pegawai kurang komunikatif. Tidak ada ruang publik untuk menyampaikan segala kendala yang terjadi. ${ }^{30}$

Dalam hal ini seorang dosen tetap dari Fakultas Dakwah dan Komunikasi, Syakdiah S. Ag, M. Ag menerangkan bahwa pegawai seharusnya menyampaikan

\footnotetext{
${ }^{29}$ Hasil wawancara penulis dengan Jovial Pally (Mahasiswa Fakultas Adab dan Humaniora UIN Ar-Raniry), Banda Aceh, 6 April 2015

${ }^{30}$ Hasil wawancara penulis dengan Rayful Mudassir (Mahasiswa Fakultas Dakwah dan Komunikasi UIN Ar-Raniry), Banda Aceh, 6 April 2015
} 
dan mengajak dosen untuk turut ambil andil dalam permasalahan yang ada. Namun dosen yang diajak hanya sesuai dengan kriteria permasalahan yang terjadi, dalam artian tidak seluruh dosen berhak ikut serta. Informan juga tidak mengelakkan bahwa di fakultas terkadang ada permasalahan akibat perbedaan persepsi antara dosen dan pegawai.

Sebuah komunikasi dikatakan berhasil apabila menguntungkan kedua belah pihak. Apabila ada yang pihak yang tidak memperoleh kesamaan makna bahkan tersakiti, berarti tidak berjalan baik proses komunikasinya. ${ }^{31}$ Pada komunikasi dua arah terjadi diskusi antara pengirim pesan dan penerima pesan sehingga penerima pesan akan merasa puas. sebaliknya pada komunikasi satu arah disamping penerima pesan merasa tidak puas, juga paling besar kemungkinan terjadinya kabar anginan. ${ }^{32}$

Iklim komunikasi dalam organisasi mempunyai konsekuensi penting bagi pergantian dan masa kerja pegawai dalam organisasi. Iklim komunikasi yang positif cenderung meningkatkan dan mendukung komitmen pada organisasi. Proses-proses interaksi yang terlibat dalam perkembangan iklim komunikasi organisasi juga memberi andil pada beberapa pengaruh penting dalam restrukturisasi, reorganisasi, dan dalam menghidupkan kembali unsur-unsur dasar organisasi.

Penelitian yang merujuk terhadap iklim komunikasi organisasi yang terjadi di UIN Ar-Raniry antar anggota organisasi dalam hal ini dosen, dan pegawai ternyata dapat dikatakan tertutup. Karena adanya beberapa persepsi yang timbul diakibatkan adanya perbedaan pemahaman, wewanang kebijakan, serta penggunaan bahasa komunikasi yang kurang baik antar anggota organisasi. Hal ini berdasarkan penelitian yang ternyata banyak ditemukannya kelompok-kelompok kecil yang terbentuk dengan atas faktor-faktor kedekatan dalam situasi nonformal. Sehingga menyebabkan sebagian anggota hanya akan berkomunikasi dalam hal penyebaran informasi terhadap beberapa anggota saja yang dianggap dekat.

${ }^{31}$ Hasil wawancara penulis dengan seorang dosen Fakultas Adab dan Humaniora yang tidak ingin disebutkan namanya, 7 April 2015

${ }^{32}$ Edy, Buday, h. 46 


\section{KESIMPULAN}

Adapun dari hasil penelitian yang telah dilakukan, maka diperoleh kesimpulan sebagai berikut:

Proses komunikasi organisasi yang terjadi kamps UIN Ar-Raniry ternyata tidak selamanya berjalan dengan efektif. Adanya miscommunication antara dosen dan pegawai telah banyak mempengaruhi akan kepuasan mahasiswa. Dalam hal kegiatan perkuliahan (belajar-mengajar), fungsi dosen Penasehat Akademik (PA), dan proses bimbingan skripsi.

Iklim komunikasi organisasi yang terjadi dalam fakultas di UIN Ar-Raniry antar anggota organisasi dalam hal ini dosen, pegawai, dan mahasiswa ternyata dapat dikatakan tertutup. Karena adanya beberapa persepsi-persepsi yang timbul diakibatkan adanya perbedaan pemahaman, wewanang kebijakan, serta penggunaan bahasa komunikasi yang kurang baik antar anggota organisasi (fakultas). Hal ini berdasarkan penelitian yang ternyata banyak ditemukannya kelompok-kelompok kecil yang terbentuk dengan atas faktor-faktor kedekatan dalam situasi nonformal. Sehingga menyebabkan sebagian anggota hanya akan berkomunikasi dalam hal penyebaran informasi terhadap beberapa anggota saja yang dianggap dekat.

\section{DAFTAR PUSTAKA}

Arikunto, Suharsimi. Prosedur Penelitian Suatu Pendekatan Praktik. Jakarta: PT Rineka Cipta, 2006.

Abbas, Syahrizal. Manajemen Perguruan Tinggi: Beberapa Catatan. Jakarta: Kencana, 2009.

Bungin, Burhan. Sosiologi Komunikasi: Teori, Paradigma, dan Diskursus Teknologi Komunikasi di Masyarakat. Jakarta: Kencana, 2009. Metode Penelitian Kualitatif. Jakarta: Kencana, 2006.

Changara, Hafied. Pengantar Ilmu Komunikasi. Jakarta: PT Raja Grafindo Persada, 2007. Persada, 2014.

Perencanaan dan Strategi Komunikasi. Jakarta: PT Raja Grafindo

Curtis, Dan B, et. al.,Komunikasi Bisnis dan Profesional. Bandung: Remaja Rosdakarya, 1996. 
Danesi, Marcel. Encyclopedia of Media and Communication. University of Toronto Press, 2013.

Denim, Inovasi Pendidikan, cet ketiga. Bandung: Pustaka Setia, 2002.

Depag RI. Alquran dan terjemahannya. Bandung: Syaamil Cipta Media, 2005.

Drajat, Amroeni. Komunikasi Islam dan Tantangan Modernitas. Bandung: Ciptapustaka Media Perintis, 2008.

Efendy, Onong Uchana. Ilmu Komunikasi, Teori dan Praktek. Bandung: Rosdakarya, 2007.

Dinamika Komunikasi. Bandung: Remaja Rosda Karya, 1986.

Gaffar, Mohammad Fakry. Komunikasi Organisasi: Teori dan Proses. Diktat kuliah jurusan Administrasi Pendidikan IKIP. Bandung: Ikip Bandung, 1983.

Goldhaber, Gerald M. Organizational Communication. USA: Brown Publisher, 1990.

Handoko, T. Hani. Manajemen, Edisi 2. Yogyakarta: BPFE-Yogyakarta, 1998. 